\title{
Enhanced production of napthoquinone metabolite (shikonin) from cell suspension culture of Arnebia sp. and its up-scaling through bioreactor
}

\author{
Komal Gupta $\cdot$ Shashank Garg $•$ Joginder Singh • \\ Manoj Kumar
}

Received: 16 January 2013/ Accepted: 29 May 2013/Published online: 9 June 2013

(c) The Author(s) 2013. This article is published with open access at Springerlink.com

\begin{abstract}
Cell culture in shake flask and air-lift bioreactor was carried out to exploit the potential of Arnebia sp. for napthoquinone metabolite production. Cell suspension cultures of Arnebia were established from friable callus in liquid MS medium supplemented with 6-benzylaminopurine (BAP) $(10 \mu \mathrm{M})$ and indole-3-butyric acid (IBA) $(5 \mu \mathrm{M})$. Growth kinetic studies were done by using settled cell volume and fresh/dry cell weight method. Suspension cultures were maintained by sub-culturing at 10 days interval. A two-stage culture system is employed using growth medium (GM) and modified M9 medium (production medium) for cell biomass and naphthoquinone pigment production, respectively. Results showed that cultivation of cells under dark conditions at room temperature $\left(25 \pm 2{ }^{\circ} \mathrm{C}\right)$ enhanced the cell biomass from 100 to $625 \mathrm{~g} \mathrm{l}^{-1}$. The pigment production was also found to be increased in dark conditions at room temperature. Alkaline $\mathrm{pH}$ found to have positive effect on pigment yield. In case of $\mathrm{M} 9$ medium constituents, absence of $\mathrm{Na}_{2} \mathrm{SO}_{4}$ does not affect the pigment yield. The current approaches have the cumulative effect to meet an increased level of $(25.5 \mu \mathrm{g} /$ $\mathrm{ml})$ metabolite production in air-lift bioreactor.
\end{abstract}

\footnotetext{
S. Garg · M. Kumar ( $₫)$

Department of Biotechnology, Lovely Professional

University, Punjab, India

e-mail: manojjnu@gmail.com

K. Gupta

NIT, Surathkal, Karnataka, India

J. Singh

School of Biotechnology and Bio sciences,

Lovely Professional University, Punjab, India
}

Keywords Secondary metabolites - Plant cell culture · Air-lift bioreactor $\cdot$ Shikonin

\section{Introduction}

The Indian Himalayan region (IHR) is a rich reservoir of biodiversity in the world. Over 1,748 species of medicinal and aromatic plants reported from IHR are used in different systems of medicine (Kandari et al. 2008). There are two types of plants derived molecules: (1) primary metabolites, and (2) secondary metabolites. Primary metabolites such as nucleic acids, proteins, carbohydrates and fats are primary compounds because of their roles in basic cell metabolism, and are usually "high volume low value" chemicals. Secondary metabolites are biosynthetically derived from primary compounds and are more limited in distribution and produced in smaller quantities. They tend to be synthesized in specialized cell types and at distinct development stages and difficult to synchronize the extraction and purification of these metabolites. Secondary metabolites such as shikonin, anthocyanin, hyoscyamine, vincristine, etc., has no apparent physiological function, but have ecological roles, e.g., attractant and chemical defense. Human use secondary metabolites as medicines, flavorings, and recreational drugs. Secondary metabolites are "high value low volume" products (Katare et al. 2009; Verpoorte and Alfermann 2000; Babula et al. 2009).

Arnebia (family Boraginaceae), commonly known as "Ratanjot", is an important and valuable plant species found at high altitude of Western Himalayan region $(4,000-4,200 \mathrm{~m}$ amsl). It has been used as a natural dye for coloring silk and cosmetics, food additives and medicine. Its roots possess naphthoquinone pigments or shikonin derivatives having medicinal properties such as antimicrobial, 
anticancer, antipyretic and anti-inflammatory (Saker et al. 2012; Verpoorte et al. 2002; Manjkhola and Dhar 2002). These properties of plant are attributed to the presence of shikonin derivatives. Owing to these properties, genus Arnebia is over-exploited and therefore, placed under the category of critically endangered species. The plants are very difficult to cultivate through conventional agriculture (possess third level of difficulty in seed germination) (Malik et al. 2011).

In this regard, plant cell culture seems to be a promising technique for production of naphthoquinone pigments under in vitro conditions (Onrubia et al. 2012; Verpoorte et al. 2002; Sharma et al. 2008). Several attempts have been made in recent past to enhance the production level which are very much significant for phytotherapeutical applications (Hussain et al. 2012).

In consideration of the above facts, the present study was undertaken with an aim to produce naphthoquinone pigment through cell culture of Arnebia sp. and its scale-up from shake-flask to air-lift bioreactor. This will not only help in meeting the industrial demand of these metabolites, but also lead to the conservation of the useful species in their natural habitat.

\section{Materials and methods}

Establishment of in vitro callus culture

\section{Culture media, plant growth regulators and glassware}

Murashige and Skoog (MS) medium (Chattopadhyay et al. 2002) was used for induction of callus from different explants. Sucrose (3\%; w/v) was added as a carbohydrate source and agar $(0.8 \%$; w/v) was incorporated as a gelling agent. Different plant growth regulators (PGRs), i.e., kinetin $(\mathrm{Kn})$ and 2,4-dichlorophenoxyacetic acid (2,4-D), 6-benzylaminopurine (BAP) and indole-3-butyric acid (IBA), BAP and 2,4-D, 2,4-D and 3, 6-dichloro-2-methoxybenzoic acid (DICAMBA) were used in factorial combinations (Table 1). PGR-free media served as control. The $\mathrm{pH}$ of the media was adjusted to 5.75 prior to autoclaving.

\section{Plant material and sterilization}

Leaf explants excised from the young plants growing in polyhouse were washed in running tap water for 5-10 min. The explants $(5-7 \mathrm{~cm})$ were rinsed in distilled water having 1-2 drops of liquid detergent (Teepol or Tween-20) for $10 \mathrm{~min}$ followed by $5 \mathrm{~min}$ washing with distilled water. The leaves were then surface sterilized with bavistin $(0.02 \%$ $\mathrm{w} / \mathrm{v})$ and streptomycin $(0.02 \% \mathrm{w} / \mathrm{v})$ for $10 \mathrm{~min}$ followed by washing with distilled water thrice. The explants were then disinfected by $70 \%$ ethyl alcohol treatment for 30-40 s. The leaves were then treated with $0.01 \% \mathrm{HgCl}_{2}$ (having 1-2 drops of tween-20) for 5 min followed by five washings with sterile distilled water inside the laminar airflow.

\section{Inoculation}

The leaf explants were dissected into small pieces $(1.0-1.5 \mathrm{~cm})$ and were inoculated into petri plates placing adaxial side in contact with solid MS medium with and without growth regulators. Cultures were kept at $25 \pm 2{ }^{\circ} \mathrm{C}$ under dark condition.

Callus induction and proliferation The percentage for callus induction can be calculated by the following formula:

Callus induction $(\%)=\frac{\text { Number of calli }}{\text { Number of explants inoculated }} \times 100$.

Establishment of cell suspension culture

The suspension cultures were established using growth medium (GM) (MS medium supplemented with BAP $(10 \mu \mathrm{M})$ and IBA $(5 \mu \mathrm{M}))$ as earlier standardized at the host institute. Sucrose (3\% w/v) was added as carbohydrate source. The $\mathrm{pH}$ of media was adjusted to 5.75 prior to autoclaving. The cultures were kept on shaker set at $100 \mathrm{rpm}, 25 \pm 2{ }^{\circ} \mathrm{C}$ under dark conditions and maintained with regular sub-culturing at 10 days interval.

\section{Growth kinetics}

The following methods were employed for studying the growth kinetics:

(a) Settled cell volume (SCV) SCV was determined by allowing a cell suspension to sediment in the side arm of the flask. It is reported as the percentage of the total volume of suspension occupied by the cell mass.

(b) Fresh and dry cell weight To measure fresh weight cell biomass was harvested by sieving suspension cultures through $40 \mu \mathrm{m}$ mesh and weighed on a balance immediately, to reduce variations caused by water evaporation. Dry weight was estimated by drying the fresh tissue at $60{ }^{\circ} \mathrm{C}$ in a convection oven, until it reached constant weight (usually 12-14 h). Fresh weight was reported as gram, fresh weight per liter $\left(\mathrm{g}, \mathrm{FW}^{-1}\right)$, while dry weight was reported as gram, dry weight per liter $\left(\mathrm{g}, \mathrm{DW} \mathrm{L} \mathrm{L}^{-1}\right)$.

Pigment production

A two-stage culture system was adopted, i.e., cell growth in GM and pigment in modified M9 medium, i.e., production 
Table 1 Combinations of PGRs used for studying the effect of salts on callus induction of Arnebia

\begin{tabular}{|c|c|c|c|c|}
\hline \multirow[t]{2}{*}{ PGR } & \multicolumn{4}{|l|}{$2,4-\mathrm{D}$} \\
\hline & $0 \mu \mathrm{M}$ & $2 \mu \mathrm{M}$ & $5 \mu \mathrm{M}$ & $10 \mu \mathrm{M}$ \\
\hline \multicolumn{5}{|l|}{ Kn } \\
\hline $0 \mu \mathrm{M}$ & $0,0(\mathrm{~T} 1)$ & $0,2(\mathrm{~T} 2)$ & $0,5(\mathrm{~T} 3)$ & 0,10 (T4) \\
\hline $2 \mu \mathrm{M}$ & 2,0 (T5) & 2,2 (T6) & 2,5 (T7) & 2,10 (T8) \\
\hline $5 \mu \mathrm{M}$ & 5,0 (T9) & 5,2 (T10) & 5,5 (T11) & $5,10(\mathrm{~T} 12)$ \\
\hline $10 \mu \mathrm{M}$ & 10,0 (T13) & 10,2 (T14) & 10,5 (T15) & 10,10 (T16) \\
\hline \multirow[t]{2}{*}{ PGR } & \multicolumn{4}{|l|}{ IBA } \\
\hline & $0 \mu \mathrm{M}$ & $2 \mu \mathrm{M}$ & $5 \mu \mathrm{M}$ & $10 \mu \mathrm{M}$ \\
\hline \multicolumn{5}{|l|}{ BAP } \\
\hline $0 \mu \mathrm{M}$ & 0,0 (T17) & 0,2 (T18) & 0,5 (T19) & $0,10(\mathrm{~T} 20)$ \\
\hline $2 \mu \mathrm{M}$ & $2,0(\mathrm{~T} 21)$ & 2,2 (T22) & 2,5 (T23) & $2,10(\mathrm{~T} 24)$ \\
\hline $5 \mu \mathrm{M}$ & $5,0(\mathrm{~T} 25)$ & 5,2 (T26) & 5,5 (T27) & $5,10(\mathrm{~T} 28)$ \\
\hline $10 \mu \mathrm{M}$ & 10,0 (T29) & 10,2 (T30) & 10,5 (T31) & $10,10(\mathrm{~T} 32)$ \\
\hline \multirow[t]{2}{*}{ PGR } & \multicolumn{4}{|l|}{$2,4-\mathrm{D}$} \\
\hline & $0 \mu \mathrm{M}$ & $2 \mu \mathrm{M}$ & $5 \mu \mathrm{M}$ & $10 \mu \mathrm{M}$ \\
\hline \multicolumn{5}{|l|}{ BAP } \\
\hline $0 \mu \mathrm{M}$ & 0,0 (T33) & 0,2 (T34) & 0,5 (T35) & 0,10 (T36) \\
\hline $2 \mu \mathrm{M}$ & 2,0 (T37) & 2,2 (T38) & 2,5 (T39) & $2,10(\mathrm{~T} 40)$ \\
\hline $5 \mu \mathrm{M}$ & $5,0(\mathrm{~T} 41)$ & $5,2(\mathrm{~T} 42)$ & 5,5 (T43) & $5,10(\mathrm{~T} 44)$ \\
\hline $10 \mu \mathrm{M}$ & $10,0(\mathrm{~T} 45)$ & 10,2 (T46) & 10,5 (T47) & $10,10(\mathrm{~T} 48)$ \\
\hline \multirow[t]{2}{*}{ PGR } & \multicolumn{4}{|l|}{$2,4-\mathrm{D}$} \\
\hline & $0 \mu \mathrm{M}$ & $2 \mu \mathrm{M}$ & $2.5 \mu \mathrm{M}$ & $5 \mu \mathrm{M}$ \\
\hline \multicolumn{5}{|l|}{ Dicamba } \\
\hline $0 \mu \mathrm{M}$ & 0.0 (T49) & 0,2 (T50) & $0,2.5$ (T51) & 0,5 (T52) \\
\hline $2 \mu \mathrm{M}$ & 2,0 (T53) & 2,2 (T54) & $2,2.5$ (T55) & 2,5 (Т56) \\
\hline $2.5 \mu \mathrm{M}$ & $2.5,0$ (T57) & $2.5,2$ (T58) & $2.5,2.5$ (T59) & $2.5,5$ (T60) \\
\hline $5 \mu \mathrm{M}$ & 5,0 (T61) & 5,2 (T62) & $5,2.5$ (T63) & 5,5 (T64) \\
\hline
\end{tabular}

medium (PM) (Katare et al. 2009). Sucrose (5 \%; w/v) was added as carbohydrate source. The $\mathrm{pH}$ of the media was adjusted to 6.00 prior to autoclaving.

Physical factors versus cell growth and pigment production

To study the effect of different factors on cell growth and pigment production in cell suspension culture, the cells from growth medium were inoculated at $10 \%$ inoculum density in GM and PM. The cultures were kept on shaker set at $100 \mathrm{rpm}$, temperature at $25 \pm 2{ }^{\circ} \mathrm{C}$ and incubated under required illumination conditions.

\section{Light conditioning}

To study the effect of light, cell suspension cultures were incubated under continuous light (photosynthetic photon flux density (PPFD), $70 \mu \mathrm{mol} \mathrm{m} \mathrm{m}^{-2} \mathrm{~s}^{-1}$ ) or complete darkness. Differential exposures of illumination period on pigment production from cell suspension cultures were determined (Table 2).

\section{Effect of $p H$}

To investigate the effect of $\mathrm{pH}$ on cell growth and pigment production, cells were incubated in GM and PM. with varied $\mathrm{pH}$ (ranging from 3.75 to 9.75 ). The $\mathrm{pH}$ of the media was adjusted with $0.1 \mathrm{~N} \mathrm{HCl}$ or $0.1 \mathrm{M} \mathrm{KOH}$ prior to autoclaving. The flasks were incubated in dark condition at $25 \pm 2{ }^{\circ} \mathrm{C}$ on shaker set at $100 \mathrm{rpm}$. Three replicates were used for each treatment.

M9 medium constituents and pigment production

To investigate the effect of individual component of M9 medium on pigment production, cells were inoculated in production medium having one component missing as per 
Table 2 Effect of light exposure duration on shikonin production

\begin{tabular}{lll}
\hline Replicates & \multicolumn{2}{c}{ Shikonin $(\mu \mathrm{g} / \mathrm{ml})$} \\
\cline { 2 - 3 } & Mean & $\mathrm{SD}$ \\
\hline $\mathrm{R} 1$ = treatment under 2 days dark +8 days light & 11.1 & 1.249 \\
$\mathrm{R} 2=$ treatment under 4 days dark +6 days light & 10.75 & 1.671 \\
$\mathrm{R} 3=$ treatment under 6 days dark +4 days light & 24.95 & 2.144 \\
$\mathrm{R} 4=$ treatment under 8 days dark +2 days light & 12.95 & 2.308 \\
$\mathrm{R} 5=$ treatment under 10 days dark & 11.90 & 1.61 \\
$\mathrm{R} 6$ = treatment under 10 days light & 6.00 & 0.655 \\
\hline
\end{tabular}

Table 3. Treatments were kept on shaker set at $100 \mathrm{rpm}$, at $25 \pm 2{ }^{\circ} \mathrm{C}$ in dark conditions.

Spectrophotometric analysis of shikonin derivatives

The quantification of shikonin derivatives was done at 2-day intervals in all the treatments. To release the pigment from cells, suspension cultures were sieved through $40 \mu \mathrm{m}$ mesh and centrifuged for $15 \mathrm{~min}$ at $10,000 \mathrm{~g}$ in Eppendorf tubes containing iso-amyl alcohol. The shikonin derivatives in the organic phase obtained being recovered as a blue aqueous solution by using $1 \mathrm{ml}$ of $2.5 \% \mathrm{KOH}$.
Absorbance of samples was recorded at $620 \mathrm{~nm}$ using spectrophotometer (Hussain et al. 2012, 2011).

\section{Standard shikonin solution}

A total of $1 \mathrm{mg}$ shikonin was dissolved in $2 \mathrm{ml}$ iso-amyl alcohol to make $500 \mathrm{ppm}$ solution. This solution was diluted 50 times to make $10 \mathrm{ppm}$ solution $(0.01 \mathrm{mg} / \mathrm{ml})$. $200 \mu \mathrm{l}$ of each concentration of shikonin solution was taken in $2 \mathrm{ml}$ Eppendorf tube and $1 \mathrm{ml}$ of $\mathrm{KOH}(2.5 \%)$ was added to it. The solution was centrifuged at $10,000 \mathrm{~g}$ for $15 \mathrm{~min}$ and allowed to stand for 10-15 min. The upper oily layer was removed and OD of blue colored solution thus obtained recorded at $620 \mathrm{~nm}$. Blank was prepared with $200 \mu$ iso-amyl alcohol instead of shikonin solution; all other steps being as stated above. This calibration curve was used to determine shikonin derivatives in cells and culture medium.

Scale-up in bioreactor

\section{Shake-flask experiments}

Shake-flask experiments were performed with $10 \%$ inoculum density in $250 \mathrm{ml}$ glass Erlenmeyer flasks containing

Table 3 Effect of PGRs on callus induction

\begin{tabular}{|c|c|c|c|c|c|c|c|}
\hline Treatment & Response & Treatment & Response & Treatment & Response & Treatment & Response \\
\hline $\mathrm{T} 1$ & \multirow{4}{*}{$*$} & $\mathrm{~T} 17$ & \multirow{15}{*}{$* * *$} & T33 & & $\mathrm{T} 49$ & \multirow{16}{*}{$* *$} \\
\hline $\mathrm{T} 2$ & & $\mathrm{~T} 18$ & & T34 & & T50 & \\
\hline T3 & & T19 & & T35 & & T51 & \\
\hline $\mathrm{T} 4$ & & $\mathrm{~T} 20$ & & T36 & & $\mathrm{T} 52$ & \\
\hline $\mathrm{T} 5$ & $*$ & $\mathrm{~T} 21$ & & T37 & & T53 & \\
\hline T6 & $* *$ & $\mathrm{~T} 22$ & & T38 & & T54 & \\
\hline $\mathrm{T} 7$ & & $\mathrm{~T} 23$ & & T39 & & T55 & \\
\hline $\mathrm{T} 8$ & & $\mathrm{~T} 24$ & & $\mathrm{~T} 40$ & & T56 & \\
\hline $\mathrm{T} 9$ & $* *$ & $\mathrm{~T} 25$ & & $\mathrm{~T} 41$ & & T57 & \\
\hline $\mathrm{T} 10$ & $* * * *$ & $\mathrm{~T} 26$ & & $\mathrm{~T} 42$ & $* *$ & T58 & \\
\hline $\mathrm{T} 11$ & & $\mathrm{~T} 27$ & & $\mathrm{~T} 43$ & & T59 & \\
\hline $\mathrm{T} 12$ & & $\mathrm{~T} 28$ & & $\mathrm{~T} 44$ & & T60 & \\
\hline $\mathrm{T} 13$ & & $\mathrm{~T} 29$ & & $\mathrm{~T} 45$ & & T61 & \\
\hline $\mathrm{T} 14$ & $* * * *$ & T30 & & $\mathrm{T} 46$ & $* * *$ & $\mathrm{~T} 62$ & \\
\hline $\mathrm{T} 15$ & $* * * *$ & T31 & & $\mathrm{T} 47$ & & $\mathrm{~T} 63$ & \\
\hline $\mathrm{T} 16$ & & T32 & $* * * *$ & $\mathrm{~T} 48$ & & T64 & \\
\hline
\end{tabular}

NIL columns represent no swelling of explants and induction up to 40 days of incubation

* Swelling in all the explants after 20 days but induction was observed only in one explant after 30 days

** Swelling in all the explants after 15 days but induction was observed only in explants after 20 days

*** Swelling in all the explants after 20 days but induction was observed only in one explant after 30 days

**** Swelling in all the explants after 20 days but induction was observed only in one explant after 30 days 
$50 \mathrm{ml}$ of GM or PM for the pigment production. Two types of bioreactors were used as mentioned below:

\section{Stirred-tank bioreactor}

The modular bench-top, water-jacketed, glass vessel stirred-tank bioreactor (Bio Flo 110) having 2 L working volume was used for scale-up studies. The medium agitation was done at $100 \mathrm{rpm}$ using top-driven motor having six-blade turbine impellers. The parameters like temperature $\left(25 \pm 2{ }^{\circ} \mathrm{C}\right)$ and $\mathrm{pH}$ (5.75 for GM and 6.00 for PM, prior to autoclaving) were set at the value as optimized during shake-flask experiments. The dissolved oxygen was supplied at $21 \mathrm{~min}^{-1}$ using compressed air. Proportional integral derivative (PID) of biocontroller unit controlled the set parameters during bioreactor cultivation. The inoculation was done in sterile conditions under laminar airflow to avoid contamination.

\section{Air-lift bioreactor}

The bench-top, water-jacketed with internal concave bottom section glass vessel air-lift bioreactor (Biostat Bplus) of $2 \mathrm{~L}$ working volume was also used for scale-up studies. Temperature was set at $25 \pm 2{ }^{\circ} \mathrm{C}$, pH (set at 5.75 for growth medium and 6.00 for production medium before autoclaving) and DO is supplied with compressed air at $2 \mathrm{~L} \mathrm{~min}^{-1}$. The culture medium is mixed by gassing, where the air is introduced near the bottom via a sparger ring and rises through an internal draft tube (Table 4). Inbuilt PID controller with the bioreactor system controlled and monitored the set parameters during cultivation.

Statistical analyses

One-way ordinary ANOVA was performed for analyzing differences in shikonin production under (1) combinatorial salt treatment (2) combination of illumination and dark conditions. ANOVA was performed using GraphPad Prism (Version 5.0) statistical software at a significance level $(\alpha)$ of 0.05 .

\section{Results and discussion}

Establishment of in vitro callus cultures and callus induction

The leaf segments were inoculated in Petri plates containing MS medium supplemented with different PGR combinations for callus induction (Fig. 1) and their effect on callus induction was observed at different time intervals (Table 3). Highest frequency of callus induction was recorded in T10, T15 and T32 after 35-40 days. However, lowering the auxin concentration in T14 resulted in early induction, i.e., 25-30 days. In these treatments, all leaf segments showed callus induction. About $50 \%$ callus induction frequency was observed in MS medium supplemented with $\mathrm{Kn}(2 \mu \mathrm{M})$ and 2,4-D $(2 \mu \mathrm{M})$, BAP $(5 \mu \mathrm{M})$ and 2,4-D $(2 \mu \mathrm{M})$ and DICAMBA $(2 \mu \mathrm{M})$ and $2,4-\mathrm{D}$ $(2.5 \mu \mathrm{M})$. However, further proliferation was very slow in all the treatments tried and failed to produce friable callus. In basal MS medium (control) only swelling of leaf segments was observed, which later on turned brown.

\section{Growth kinetics}

\section{Settled cell volume (SCV)}

The results showed that the cells take about 2 days (lag phase) after inoculation to start growing actively. The exponential growth (log phase) persist for about 8 days (2-10 days of cultivation period), as evident from the Fig. 2. Thereafter the growth starts ceasing to follow stationary phase (between 10 and 16 days of cultivation) and onset of decline phase (begins from 16th day onwards).

Table 4 Effect of initial $\mathrm{pH}$ of medium on shikonin production

\begin{tabular}{|c|c|c|c|c|c|c|c|c|c|}
\hline \multirow[t]{3}{*}{ Sr. no. } & \multirow[t]{3}{*}{ Time interval (days) } & \multicolumn{8}{|c|}{ Shikonin $(\mu \mathrm{g} / \mathrm{ml})$} \\
\hline & & \multicolumn{2}{|c|}{$\mathrm{pH} 3.75$} & \multicolumn{2}{|c|}{$\mathrm{pH} 5.75$} & \multicolumn{2}{|c|}{$\mathrm{pH} 7.75$} & \multicolumn{2}{|c|}{$\mathrm{pH} 9.75$} \\
\hline & & Mean & SD & Mean & SD & Mean & $\mathrm{SD}$ & Mean & SD \\
\hline 1 & 0 & 0.5 & 0.096 & 0.525 & 0.082 & 0.525 & 0.035 & 0.5 & 0.072 \\
\hline 2 & 2 & 0.75 & 0.075 & 1.25 & 0.121 & 1.05 & 0.095 & 1.275 & 0.197 \\
\hline 3 & 4 & 1.025 & 0.109 & 2.25 & 0.252 & 1.825 & 0.175 & 2.6 & 0.319 \\
\hline 4 & 6 & 2.375 & 0.218 & 5.025 & 0.229 & 3.05 & 0.353 & 7.05 & 0.321 \\
\hline 5 & 8 & 3.2 & 0.229 & 5.8 & 0.409 & 4.675 & 0.303 & 9.3 & 1.029 \\
\hline 6 & 10 & 5.9 & 0.377 & 7.75 & 0.804 & 7.5 & 0.750 & 9.85 & 0.721 \\
\hline 7 & 12 & 6.15 & 0.242 & 8.375 & 0.533 & 8.8 & 0.393 & 10.025 & 0.801 \\
\hline
\end{tabular}


Fig. 1 Leaf explants of Arnebia sp. for callusing a swelling of leaves, $\mathbf{b}$ initiation of callus (T14), c proliferation of callus (T15), and d control
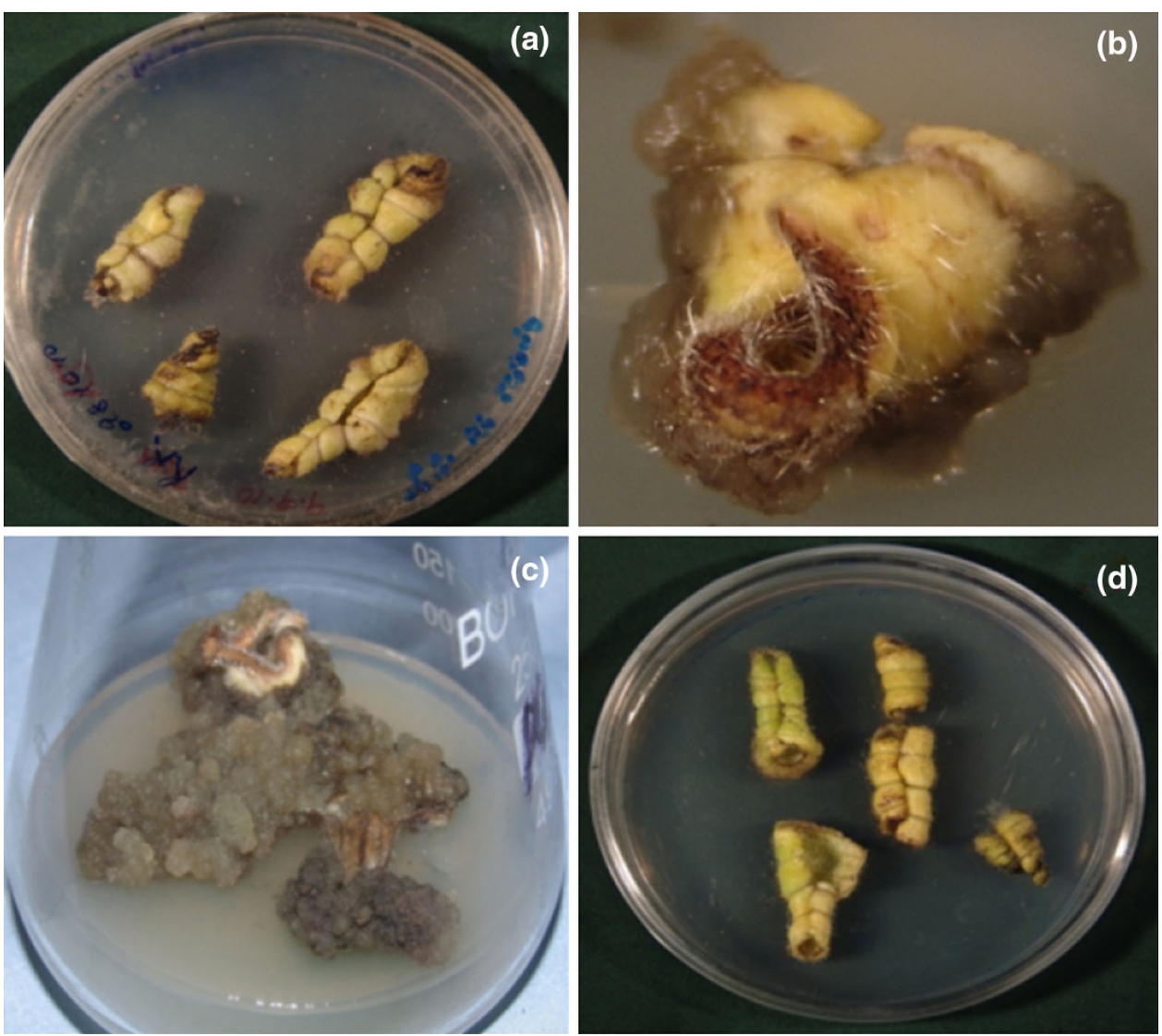

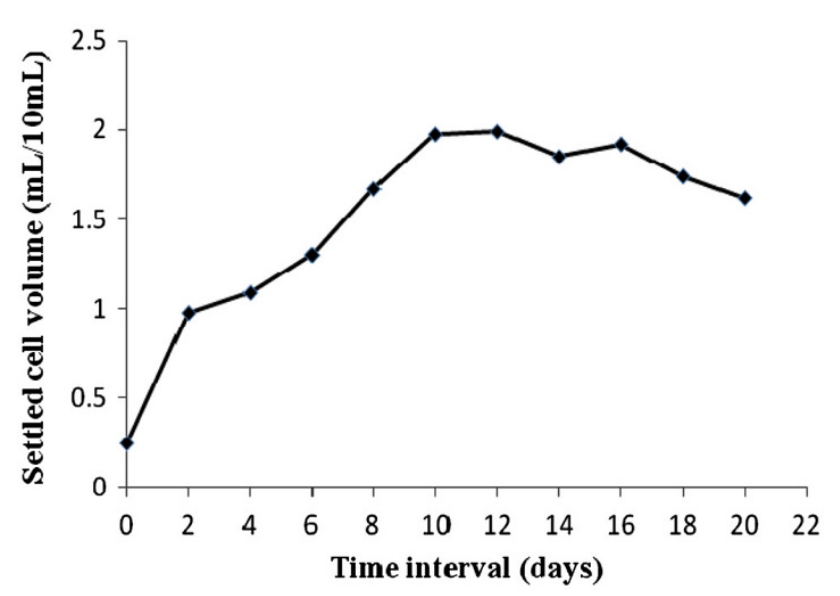

Fig. 2 Growth curve based on settled cell volume (SCV)

Hence, the results showed that the Arnebia cells have 10 days of cultivation period before fresh sub-culturing for further multiplication can be done in liquid medium.

\section{Fresh and dry weight}

The growth kinetics based on fresh and dry weight was also studied. This is more accurate method than SCV, as in this actual increase in weight being recorded. The results showed a lag phase up to 1 day, log (exponential) phase from 2 nd to 8 th day, stationary phase from 8th to 12th day and decline phase 12th day onwards (Fig. 3). The reduced lag phase and early log phase can be corroborated to the age of inoculum used, making fast cell acclimatization.

\section{Pigment production}

The already established two-stage culture system was used for pigment production. The cells grown in GM were transferred to modified M9 medium at $10 \%$ inoculum density, as described in "Materials and methods". The cultures were kept under dark conditions at $25 \pm 2{ }^{\circ} \mathrm{C}$ on shaker.

Factors affecting cell growth and pigment production in suspension culture

\section{Effect of illumination}

Cell growth The cells grown in GM under $24 \mathrm{~h}$ light as well as dark conditions revealed that cell biomass grows almost six-times higher under dark condition and increased from 5 to $31.58 \mathrm{~g}$ as compared to $20.91 \mathrm{~g}$ in the presence 

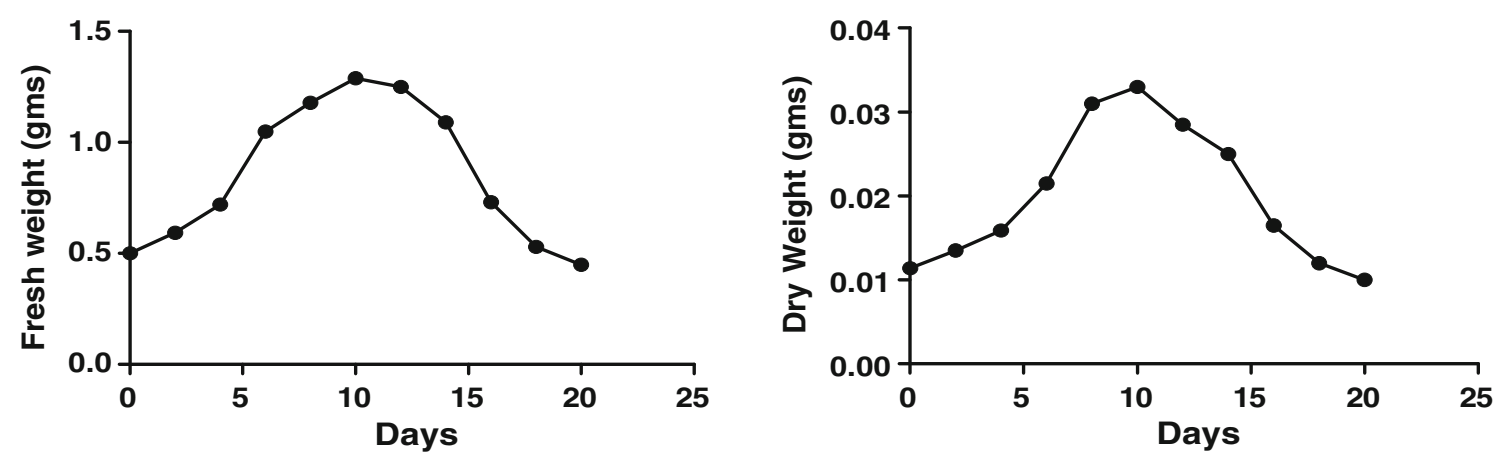

Fig. 3 Growth curve based on fresh and dry cell weight

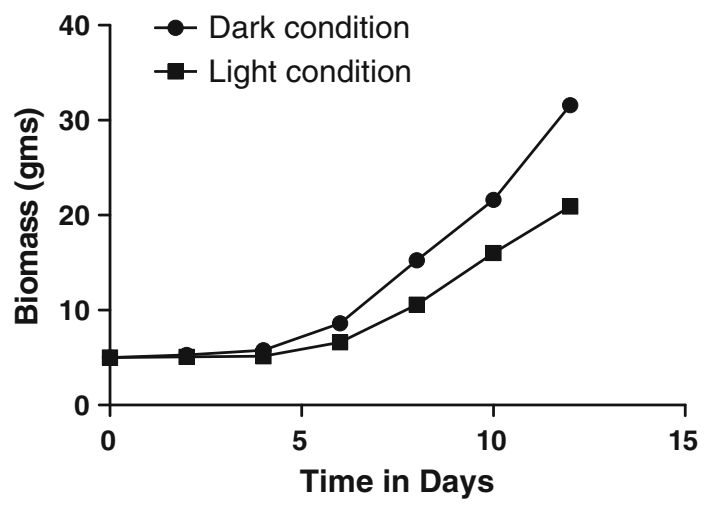

culture period in suspension culture growing under dark conditions. However, there was very less pigment formation in cells growing under the presence of light. This shows that light completely inhibits the production of pigment during earlier phase of cultivation period (Fig. 6). Results revealed that maximum shikonin content $\left(\mathrm{OD}_{620}=0.218\right)$ was observed in dark conditions after 12 days of culture period as compared to light $\left(\mathrm{OD}_{620}=0.120\right)($ Fig. 6).

Effect of illumination exposure period on pigment yield Results showed that maximum pigment production was obtained when the cell suspension culture was kept in light for 6 days and then in dark for 4 days (Fig. 7) than rest of the illumination dark period combination.

The decrease in pigment production in cultures grown

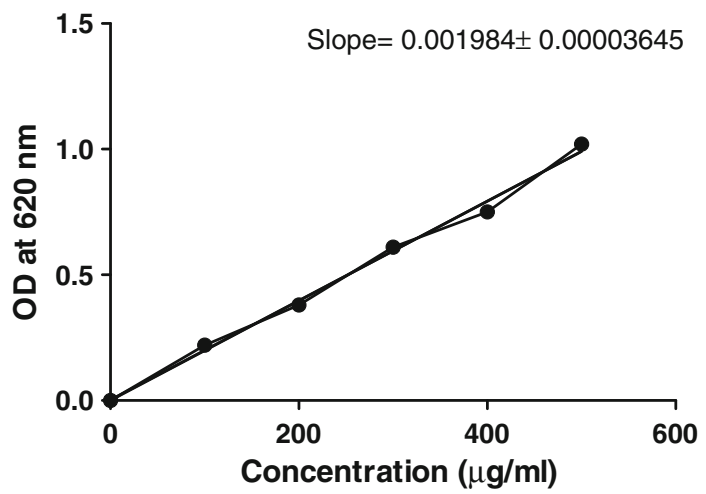

Fig. 5 Standard curve of shikonin

of light, at the end of cultivation period (Figs. 4, 5). The per cent increase in yield was calculated to be $531 \%$.

Pigment production The cells were inoculated in modified M9 medium under $24 \mathrm{~h}$ light as well as dark conditions to observe effect of illumination on pigment production. There was an increase in pigment content irrespective of light conditions till 4th day of culture but as the culture period progresses, the pigment content decreases in the presence of light, whereas in dark it continued to increase. Dark red colored pigment was observed at the end of under the presence of light is attributed to the inhibition of $p$-hydroxybenzoic acid geranyl transferase (PGT) activity-a key enzyme of shikonin biosynthesis Irradiation results in accumulation of $o$-glucosidic form of $p$-hydroxybenzoic acid (PHB). PHB is stored in vacuole of cells in its glucoside form in presence of light and upon transfer of cells to dark condition, this glucoside is hydrolyzed to give free hydroxybenzoic acid, which on further reaction

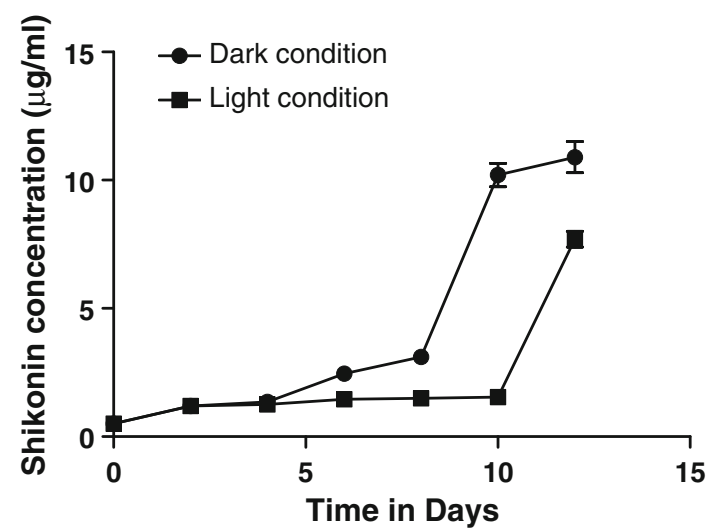

Fig. 6 Comparison of dark and light conditions on shikonin production

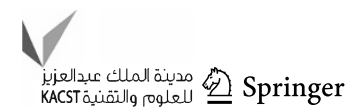




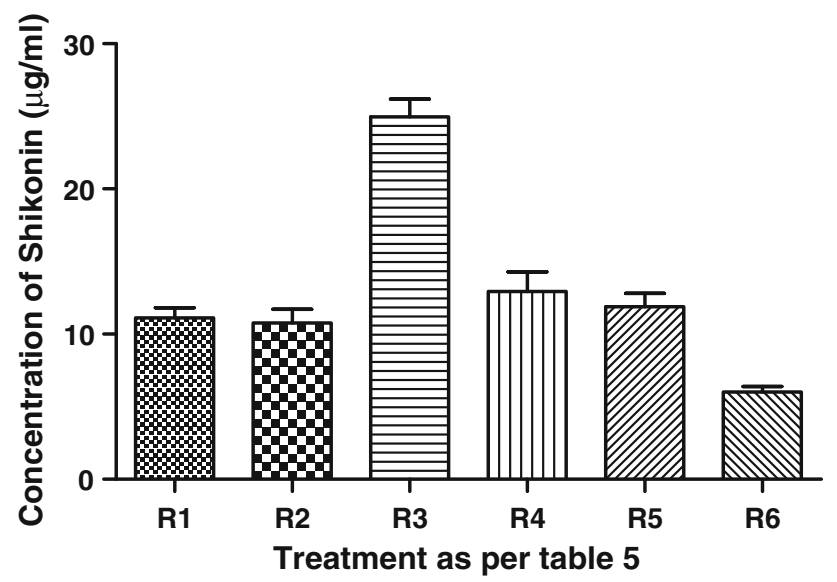

Fig. 7 Effect of light exposure period on shikonin production

metabolized to shikonin biosynthesis (Sommer et al. 1999; Xuqing and Dewei 1998).

The maximum production of naphthoquinone pigment was observed within 10 days of cultivation period, thereafter it declined. The decline was possibly due to cell death or as result of feedback inhibition caused by the accumulation of pigment. Dark condition was a pre-requisite for the biosynthesis of pigment as there was no pigment production in light. This is due to the fact that these compounds are accumulated in the underground part of the plant.

\section{Effect of $p H$}

The $\mathrm{pH}$ of the medium was found to have pronounced effect on cell biomass and pigment production. Cell growth is directly influenced by the nutritional composition of the medium, but the uptake of nutrient is mainly influenced by $\mathrm{pH}$ of the medium. The cell growth is directly influenced by the nutritional composition of the medium, but the uptake of nutrient is mainly influenced by $\mathrm{pH}$ of the medium. The various biochemical reactions occurring at the cellular level are also influenced by change in $\mathrm{pH}$ due to the specificity of $\mathrm{pH}$-dependent enzymes.

Cell growth The Arnebia cells were cultured in GM under different $\mathrm{pH}$ regime to observe its effect on biomass growth. Results revealed that cell biomass recorded almost seven-times higher growth at $\mathrm{pH} 5.75$ and increased from 5 to $35.99 \mathrm{~g}$ as compared to $18.97 \mathrm{~g}$ at $\mathrm{pH} 3.75$, after 12 days of cultivation period. The increase in yield was found to be $620 \%$. As the $\mathrm{pH}$ of the medium increased from 5.75 to 9.75 , the cell growth was found to decrease. At $\mathrm{pH} 5.75$, an increase in fresh weight of cell biomass was observed throughout the cultivation period. However, a low biomass yield was recorded in extremes of $\mathrm{pH}$, i.e., 3.75 and 9.75 (Fig. 8). The pattern of cell growth is indicative of 10 days

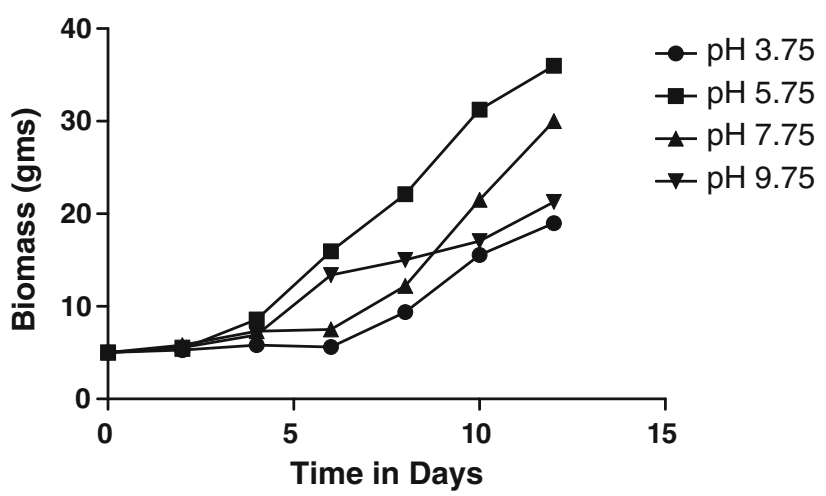

Fig. 8 Effect of initial pH of medium on biomass growth

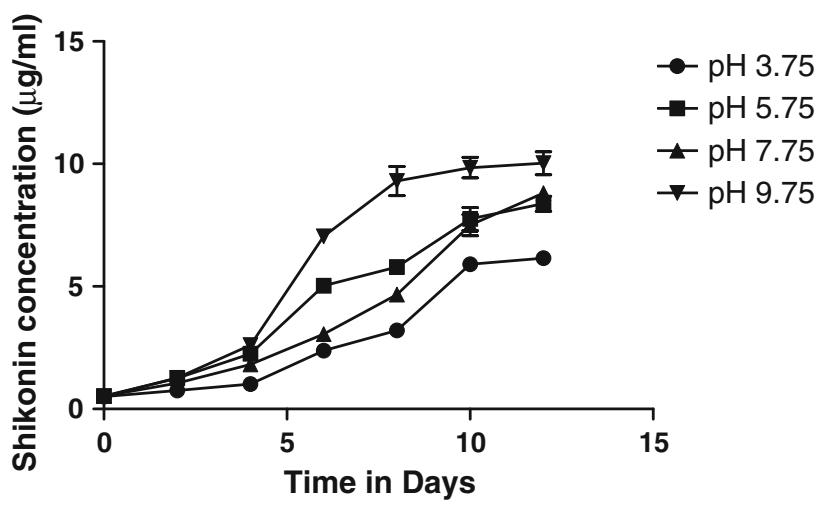

Fig. 9 Effect of initial $\mathrm{pH}$ of medium on shikonin production

sub-culturing period for maximum biomass production in cell suspension cultures.

Pigment production The cells were grown in M9 medium under different $\mathrm{pH}$ regime. Results revealed that the cells growing at high $\mathrm{pH}$ (9.75) exhibited high and early synthesis of pigment (6 days). The maximum shikonin content $\left(\mathrm{OD}_{620}=0.210\right)$ was observed at $\mathrm{pH} 9.75$, while the lowest value $\left(\mathrm{OD}_{620}=0.123\right)$ was observed at $\mathrm{pH} 3.75$ (Fig. 9). Cell growth and production of shikonin was observed to be greatly influenced by the $\mathrm{pH}$ of the respective media (Table 5). Acidic $\mathrm{pH}$ favors cell growth, whereas alkaline $\mathrm{pH}$ favors pigment production. It was observed that $\mathrm{pH}$ of the growth medium as well as that of production medium changed by 1-2 Units after autoclaving. The change was more pronounced in production medium because of the low buffering capacity of the medium. The change in $\mathrm{pH}$ after autoclaving is due to the high during sterilization temperature, which alters the composition of various nutrients and salts of the medium. The initial increase in $\mathrm{pH}$ value might result from the fast uptake and reduction of nitrates (formation of $\mathrm{OH}^{-}$) while acidification of the medium at later stages of cell culture can be associated with the uptake of ammonium ion. 
Table 5 Production of shikonin under dark and light conditions

\begin{tabular}{|c|c|c|c|c|c|}
\hline \multirow[t]{3}{*}{ Sr. no. } & \multirow[t]{3}{*}{ Time interval (days) } & \multicolumn{4}{|c|}{ Shikonin $(\mu \mathrm{g} / \mathrm{ml})$} \\
\hline & & \multicolumn{2}{|c|}{ Dark condition } & \multicolumn{2}{|c|}{ Light condition } \\
\hline & & Mean & SD & Mean & SD \\
\hline 1 & 0 & 0.5 & 0.132 & 0.5 & 0.055 \\
\hline 3 & 2 & 1.2 & 0.264 & 1.2 & 0.132 \\
\hline 3 & 4 & 1.35 & 0.229 & 1.25 & 0.079 \\
\hline 4 & 6 & 2.45 & 0.132 & 1.45 & 0.11 \\
\hline 5 & 8 & 3.1 & 0.360 & 1.49 & 0.127 \\
\hline 6 & 10 & 10.2 & 0.781 & 1.55 & 0.125 \\
\hline 7 & 12 & 10.9 & 1.044 & 7.7 & 0.529 \\
\hline
\end{tabular}

Fig. 10 Effect of salts on production of shikonin

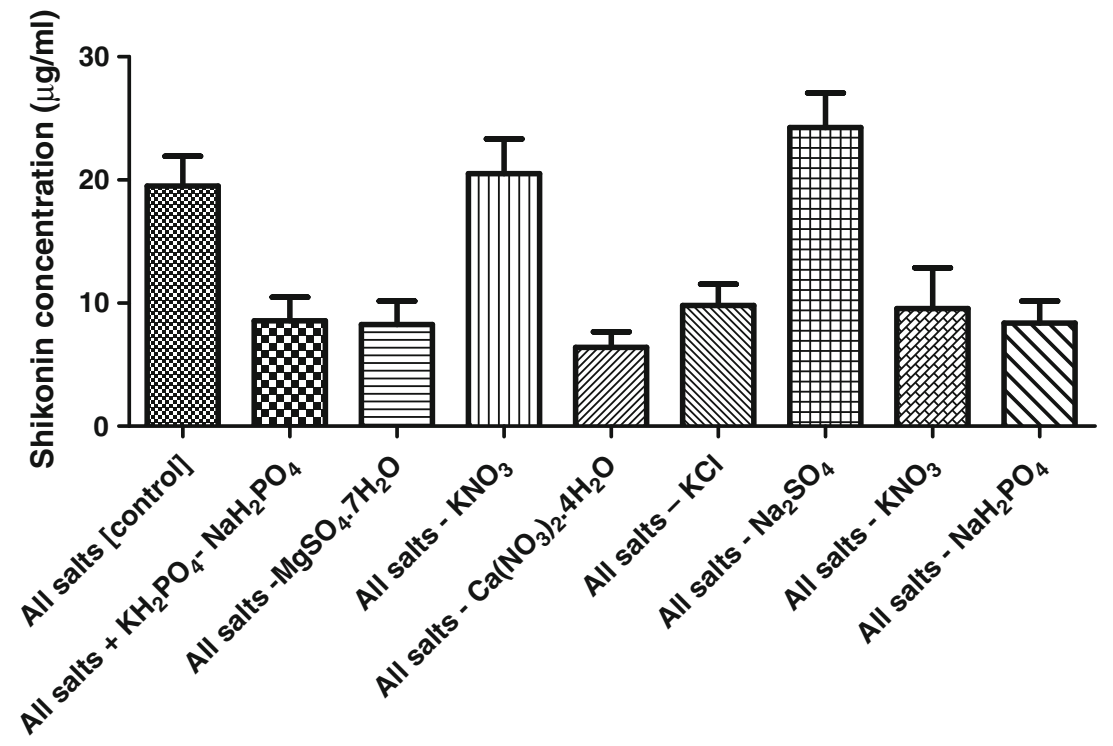

Increased production of pigment at alkaline $\mathrm{pH}$ of production medium could be correlated with the enhanced activity of PGT, one of the key regulatory enzymes of shikonin biosynthetic pathway. This enzyme catalyzes the condensation of $p$-hydroxybenzoic acid and geranyl pyrophosphate (GPP) to yield $m$-gernayl- $p$-hydroxybenzoic acid (GBA) requires the optimum $\mathrm{pH}$ which ranges from 7.1 to 9.3 for its activity (Malik et al. 2011; Xuqing and Dewei 1998).

\section{Effect of M9 medium constituents on pigment production}

The purpose of this experiment was to study the effect of individual constituents of M9 medium (Table 3) on pigment production. $\mathrm{Na}_{2} \mathrm{SO}_{4}$ is used at higher concentration $\left(1,480 \mathrm{mg} \mathrm{l}^{-1}\right)$ in $\mathrm{M} 9$ medium. It was interesting to notice that its exclusion of $\mathrm{Na}_{2} \mathrm{SO}_{4}$ (T7) does not affect the pigment yield and recorded a little higher $\mathrm{OD}$ value $\left(\mathrm{OD}_{620}=0.141\right)$ as compared to T1, i.e., control $\left(\mathrm{OD}_{620}=0.112\right)$. However, the exclusion of other constituents does not reveal any pronounced effect on metabolite yield. TSS and $\mathrm{pH}$ were found to be higher in combination where $\mathrm{MgSO}_{4} \cdot 7 \mathrm{H}_{2} \mathrm{O}$ (T3) was missing (Fig. 10).

\section{Scale-up in bioreactor}

Experiments on scale-up of cell biomass production (GM) and pigment production (modified M9) from shake flask to bioreactor was done with optimized parameters as discussed in "Materials and methods" section. The data were recorded for cell biomass and pigment production in shakeflask and different bioreactors. Results showed that the cell biomass was drastically decreased with the scale-up from shake-flask $(1,249.2 \mathrm{~g})$ to stirred-tank bioreactor (480 g) and air-lift bioreactor (450 g). However, the pigment production as evident from Table 6 is considerably higher in air-lift reactor as well as stirred-tank bioreactor (Fig. 11).

Statistical analyses

ANOVA table for evaluating the effect of M9 media constituents (as per Table 7) is given in Table 8. From 
Table 6 Production of shikonin in three different culture systems

\begin{tabular}{llll}
\hline Sr. no. & Culture system & \multicolumn{2}{l}{$\begin{array}{l}\text { Concentration of } \\
\text { shikonin produced }(\mu \mathrm{g} / \mathrm{ml})\end{array}$} \\
\cline { 3 - 4 } & & Mean & SD \\
\hline 1 & Shake-flask (2 L) & 9.7 & 3.522 \\
2 & Stirred-tank bioreactor (2 L) & 21.15 & 3.050 \\
3 & Air-lift bioreactor (2 L) & 25.5 & 5.286 \\
\hline
\end{tabular}

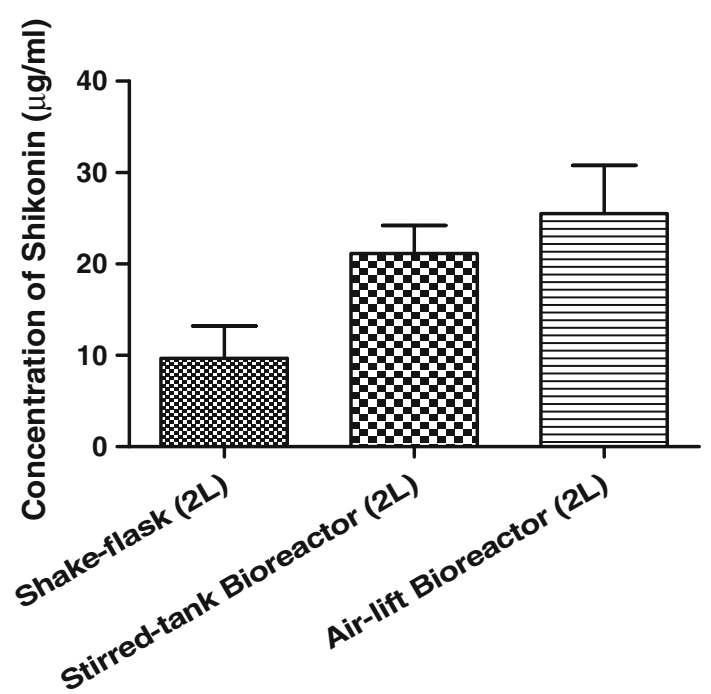

Fig. 11 Comparative histogram for produce of shikonin in 3 different culture systems

Table 8 it is revealed that there is a significant effect $(P<0.001)$ of M9 media constituents on pigment production.

Table 9 gives the ANOVA statistics for data collected after exposing the cell culture to light conditions for different duration. A very significant correlation $(P<0.001)$ is obtained between light exposure duration and pigment yield and ANOVA revealed that there is a very less probability that the variance among the means of obtained result is due to chance.

\section{Conclusion}

The present study was carried out to exploit the potential of Arnebia sp. for naphthoquinone pigment production through cell culture. Growth kinetics was studied by settled cell volume and fresh/dry cell weight methods. It was found that fresh/dry weight was more efficient to predict the growth phases.

Effect of factors like $\mathrm{pH}$, illumination and medium constituents affecting the cell growth and pigment
Table 7 Combination of salts used for studying effect on pigment production

\begin{tabular}{llcl}
\hline Sr. no. & No. of combinations & \multicolumn{2}{l}{$\begin{array}{l}\text { Shikonin concentration } \\
(\mu \mathrm{g} / \mathrm{ml})\end{array}$} \\
\cline { 3 - 4 } & & Mean & $\mathrm{SD}$ \\
\hline $\mathrm{T} 1$ & All salts [control] & 19.5 & 2.438 \\
$\mathrm{~T} 2$ & All salts $+\mathrm{KH}_{2} \mathrm{PO}_{4}-\mathrm{NaH}_{2} \mathrm{PO}_{4}$ & 8.55 & 1.931 \\
T3 & All salts: $\mathrm{MgSO}_{4} \cdot 7 \mathrm{H}_{2} \mathrm{O}$ & 8.25 & 1.920 \\
T4 & All salts: $\mathrm{KNO}_{3}$ & 20.5 & 2.825 \\
T5 & All salts: $\mathrm{Ca}\left(\mathrm{NO}_{3}\right)_{2} \cdot 4 \mathrm{H}_{2} \mathrm{O}$ & 6.4 & 1.264 \\
T6 & All salts: $\mathrm{KCl}_{2}$ & 9.8 & 1.739 \\
T7 & All salts: $\mathrm{Na}_{2} \mathrm{SO}_{4}$ & 24.25 & 2.818 \\
T8 & All salts: $\mathrm{KNO}_{3}$ & 9.55 & 3.308 \\
T9 & All salts: $\mathrm{NaH}_{2} \mathrm{PO}_{4}$ & 8.4 & 1.757 \\
\hline
\end{tabular}

Table 8 One-way ANOVA of effect of salts combination as per Table 7

\begin{tabular}{llll}
\hline$P$ value & $P<0.0001$ & \\
$P$ value summary & $* * *$ & & \\
Are means significant different? $(P<0.05)$ & Yes & & \\
Number of groups & 9 & & \\
$F$ & 24.91 & & \\
$R$ squared & 0.9172 & & \\
ANOVA table & $\mathrm{SS}$ & & \\
Treatment (between columns) & 1,062 & df & MS \\
Residual (within columns) & 95.9 & 8 & 132.7 \\
Total & 1,158 & 18 & 5.328 \\
& & 26 & \\
\hline
\end{tabular}

Table 9 One-way ANOVA of effect of light exposure duration as per Table 2

\begin{tabular}{llll}
\hline$P$ value & $P<0.0001$ & & \\
$P$ value summary & $* * *$ & & \\
Are means significant different? $(P<0.05)$ & Yes & & \\
Number of groups & 6 & & \\
$F$ & 42.04 & & \\
$R$ squared & 0.946 & & \\
ANOVA table & $\mathrm{SS}$ & df & MS \\
Treatment (between columns) & 605 & 5 & 121 \\
Residual (within columns) & 34.54 & 12 & 2.878 \\
Total & 639.5 & 17 & \\
\hline
\end{tabular}

production was also studied. Different factors affecting the cell growth and pigment production were studied. It was concluded that dark conditions at room temperature $\left(25 \pm 2{ }^{\circ} \mathrm{C}\right)$ and acidic $\mathrm{pH}(5.75)$ favors the cell growth in GM while alkaline $\mathrm{pH}$ at same conditions favors the 
pigment production. In case of M9 medium constituents, interestingly, $\mathrm{Na}_{2} \mathrm{SO}_{4}$ does not affect the pigment yield and was found at par with control. During scale-up, the cell biomass productivity decreases drastically; however, the pigment yield increased.

Finally, statistical analyses of the obtained data through ANOVA rule out any chance of random differences among the final production of pigment production and establish the fact that there is effect of constituents of M9 medium and illumination on the pigment yield.

Acknowledgments Authors acknowledge the National Institute of Technology, Karnataka, India, and Lovely Professional University, Punjab, India, for providing the space and other supports.

Open Access This article is distributed under the terms of the Creative Commons Attribution License which permits any use, distribution, and reproduction in any medium, provided the original author(s) and the source are credited.

\section{References}

Babula P, Adam V, Havel L, Kizek R (2009) Noteworthy secondary metabolites naphthoquinones- their occurrence, pharmacological properties and analysis. Curr Pharm Anal 5:47-68

Chattopadhyay S, Farkya S, Ashok K, Srivastava AK, Bisaria VS (2002) Bioprocess considerations for production of secondary metabolites by plant cell suspension cultures. Biotechnol Bioprocess Eng 7:138-149

Hussain MS, Fareed S, Ansari S, Rahman MA, Ahmad IZ, Saeed M (2012) Current approaches toward production of secondary plant metabolites. J Pharm Bioallied Sci 4:10-20

Kandari LS, Rao KS, Maikhuri RK, Chauhan K (2008) Effect of presowing, temperature and light on the seed germination of
Arnebia benthamii (Wall. ex G. Don): an endangered medicinal plant of Central Himalaya, India. Afr J Plant Sci 2(1):5-11

Katare DP, Aeri V, Bora M (2009) Secondary metabolites and metabolic engineering. J Cell Tissue Res 9(3):2027-2036

Malik S, Bhushan S, Sharma M, Ahuja PS (2011) Physico-chemical factors influencing the shikonin derivatives production in cell suspension cultures of Arnebia euchroma (Royle) Johnston, a medicinally important plant species. Cell Biol Int 35:153-158

Manjkhola S, Dhar U (2002) Conservation and utilization of Arnebia benthamii (Wall. ex G. Don) Johnston-a high value Himalayan medicinal plant. Curr Sci 83:4-25

Onrubia M, Cusidó RM, Ramirez K, Hernández-Vázquez L, Moyano E, Bonfill M, Palazon J (2012) Bio processing of plant in vitro systems for the mass production of pharmaceutically important metabolites: paclitaxel and its derivatives. Current medicinal chemistry (Online draft)

Saker MM, Farid MM, Fahmi AA, El-Mekkawy SA, Taha HS, Amin AI (2012) Large scale production of antitumor cucurbitacins from Ecballium Elaterium using bioreactor. Afr J Biotechnol 11:12974-12982

Sharma N, Sharma UK, Malik S, Bhushan S, Kumar V, Verma SC, Sharma N, Sharma M, Sinha AK (2008) Isolation and purification of acetylshikonin and b-acetoxyisovaleryl shikonin from cell suspension cultures of Arnebia euchroma (Royle) Johnston using rapid preparative HPLC. J Sep Sci 31:629-635

Sommer S, Kohle A, Yazaki K, Shimomura K, Bechthold A, Heide L (1999) Genetic engineering of shikonin biosynthesis hairy root cultures of Lithospermum erythrorhizon transformed with the bacterial $u b i C$ gene. Plant Mol Biol 39:683-693

Verpoorte R, Alfermann AW (2000) Metabolic engineering in plant secondary metabolism, 1st edn. Kluver Academic Publisher, USA, pp $1-20$

Verpoorte R, Contin A, Memelink J (2002) Biotechnology for the production of plant secondary metabolites. Phytochem Rev 1:13-25

Xuqing F, Dewei L (1998) Enhancement of shikonin production in cell suspension cultures of Arnebia euchroma employing twoliquid phase systems. Chin J Chem Eng 6(1):86-90 